\title{
Activation and selective IL-17 response of human Vy9Vס2 T lymphocytes by TLR-activated plasmacytoid dendritic cells
}

\author{
Elena Lo Presti ${ }^{1,2}$, Nadia Caccamo ${ }^{1,2}$, Valentina Orlando ${ }^{1,2}$, Francesco Dieli ${ }^{1,2}$ and \\ Serena Meraviglia ${ }^{1,2}$ \\ ${ }^{1}$ Central Laboratory of Advanced Diagnosis and Biomedical Research (CLADIBIOR), University of Palermo, Palermo, Italy \\ 2 Department of Biopathology and Medical Biotechnologies (DIBIMED), University of Palermo, Palermo, Italy \\ Correspondence to: Serena Meraviglia, email: serena.meraviglia@unipa.it \\ Keywords: $ү \delta$ T cells, plasmacyłoid dendritic cells, IL-17, TLR activation, proliferation, Immunology and Microbiology Section, Im- \\ mune response, Immunity \\ Received: July 20, 2016 \\ Accepted: August 02, 2016 \\ Published:August 31, 2016
}

\section{ABSTRACT}

Vy9Vס2 T cells and plasmacytoid dendritic cells (pDCs) are two distinct cell types of innate immunity that participate in early phases of immune response. We investigated whether a close functional relationship exists between these two cell populations using an in vitro co-culture in a human system.

pDCs that had been activated by IL-3 and the TLR9 ligand CpG induced substantial activation of $V_{Y} 9 \mathrm{~V} \delta 2 \mathrm{~T}$ cells upon co-culture, which was cell-to-cell contact dependent, as demonstrated in transwell experiments, but that did not involve any of the costimulatory molecules potentially expressed by pDCs or VY9V2 T cells, such as ICOS-L, OX40 and CD40L. Activated pDCs selectively induced IL-17, but not IFN-Y, responses of $\mathrm{VY} 9 \mathrm{~V} \delta 2 \mathrm{~T}$ cells, which was dominant over the antigen-induced response, and this was associated with the expansion of memory (both central and effector memory) subsets of $\mathrm{V}_{\mathrm{Y}} \mathrm{V} \mathrm{V} \delta 2 \mathrm{~T}$ cells.

Overall, our results provide a further piece of information on the complex relationship between these two populations of cells with innate immunity features during inflammatory responses.

\section{INTRODUCTION}

Plasmacytoid dendritic cells (pDCs) are one of the two principal subsets of human dendritic cells (DCs) and represent specialized cells for the production of type-I interferons (IFNs). They are involved in immune responses against most viruses and also act as a bridge between innate and adaptive immunity. pDCs comprise $<1 \%$ of total peripheral blood mononuclear cells (PBMCs) and can be isolated using antibodies against the surface markers BDCA-2 and BDCA-4. In humans, pDCs circulate in the blood of adults and neonates, can be located in lymphoid tissues, accumulate at inflammatory sites and also infiltrate various types of solid tumours. pDCs express a different profile of Toll like receptors (TLRs) than other subsets of DC, like TLR7 and TLR9, which are intracellular endosomal receptors for single stranded RNA and DNA [1-3]. Upon in vitro stimulation with interleukin (IL)-3 and TLR9 agonist-like CpG ODNs they acquire a typical DC morphology and many functional properties and participate to activation of other cell types like monocytes, B, NK and T lymphocytes.
Moreover, recent studies have shown that pDCs upregulate MHC class II molecules upon inflammation and induce both $\mathrm{T}$ cell mediated immunity and tolerance [4], thus highlighting their role in adaptive immunity.

$\mathrm{V} \gamma 9 \mathrm{~V} \delta 2$ cells represent a major peripheral blood $\gamma \delta \mathrm{T}$ cell subset in humans (up to $1 / 20$ of the peripheral blood lymphoid pool), which display broad reactivity against microbial agents and tumors. They recognize phosphoantigens (PAgs) of microbial (intermediates of the non-mevalonate (MVA) pathway of isoprenoid biosynthesis) and endogenous (metabolites of the MVA pathway) origin, whose production is upregulated upon cell stress [5]. Pharmacological agents can block either upstream (statins) or downstream (aminobisphosphonates (ABPs), alkylamines) MVA pathway leading, respectively, to decreased or increased intracellular isopentenyl pyrophosphate (IPP) levels. Alternatively, IPP could be presented by surface receptors unrelated to the MVA pathway. In fact, IPP metabolites can be converted into triphosphoric acid 1-adenosin-5'-yl ester 3-(3-methylbut3enyl) ester (ApppI), an ATP analogue, which could then be processed and presented at the cell surface. Butyrophilin 
(BTN) 3A1 molecule controls activation of human $\mathrm{V} \gamma 9 \mathrm{~V} \delta 2 \mathrm{~T}$ cells by direct or indirect presentation of self and non self PAgs.

Similar to CD4 and CD8 $\mathrm{T}$ cells, Vy9V82 T lymphocytes are heterogeneous and comprise distinct populations that can be distinguished on the basis of surface marker expression and effector functions, such as cytokine secretion and cytotoxicity. Naive $\left(\mathrm{T}_{\text {naive }}\right)$

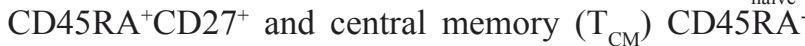
$\mathrm{CD} 27^{+}$cells express lymph node homing receptors, abound in lymph nodes, and lack immediate effector functions. Conversely, effector memory $\left(\mathrm{T}_{\mathrm{EM}}\right) \mathrm{CD}^{-} \mathrm{RAA}^{-} \mathrm{CD} 27^{-}$and terminally differentiated $\left(\mathrm{T}_{\mathrm{EMRA}}\right) \mathrm{CD} 45 \mathrm{RA}^{+} \mathrm{CD} 27^{-}$cells express receptors for migration to inflamed tissues, are poorly represented in the lymph nodes while abounding at sites of inflammation, where they display immediate effector functions (cytokine production and cytotoxicity, respectively) [6].

Since $\gamma \delta \mathrm{T}$ cells and pDCs represent distinct components of the innate compartment, we investigated on their interactions and the underlying mechanism.

\section{RESULTS}

\section{TLR-9 engagement on human pDCs induces $\mathrm{V} \gamma \mathbf{9 V \delta 2} \mathrm{T}$ cell proliferation}

Previous studies have shown that $\mathrm{V} \gamma 9 \mathrm{~V} \delta 2 \mathrm{~T}$ cell clones secrete IFN- $\gamma$ upon 24-hrs in vitro stimulation by TLR8/9-activated pDCs [7]. To ascertain the influence of $\mathrm{pDCs}$ on resting $\mathrm{V} \gamma 9 \mathrm{~V} \delta 2 \mathrm{~T}$ cells, immature $\mathrm{pDCs}$ or pDCs that had been activated by IL-3 and the TLR9 ligand CpG-A ODN2216, were cultured in vitro with CFSElabelled $\mathrm{V} \gamma 9 \mathrm{~V} \delta 2 \mathrm{~T}$ cells freshly sorted from PBMC of healthy donors. Proliferation was assessed after 6 days of culture according to loss of CFSE labelling. Cumulative data from 12 individual experiments, expressed as the mean $\pm \mathrm{SD}$, are shown in Figure 1a, and representative data are shown in Figure 1b.

Immature $\mathrm{pDCs}$ induced significant $\mathrm{V} \gamma 9 \mathrm{~V} \delta 2 \mathrm{~T}$ cells proliferation $(18.1 \% \pm 2)$, but IL-3 and CpG-A activated

a

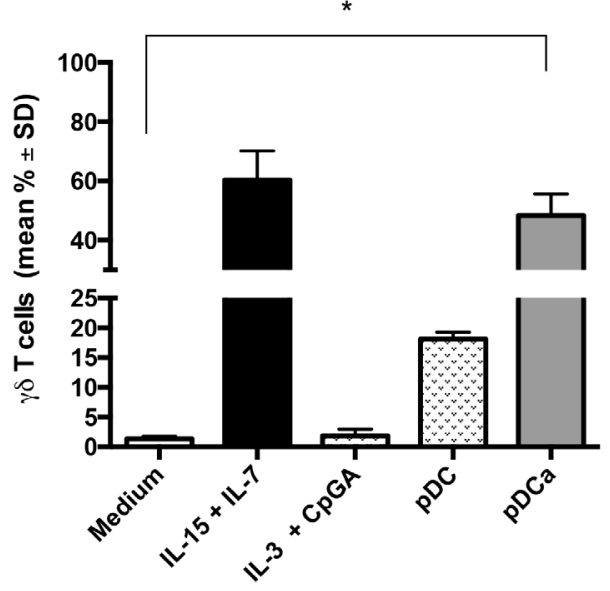

b

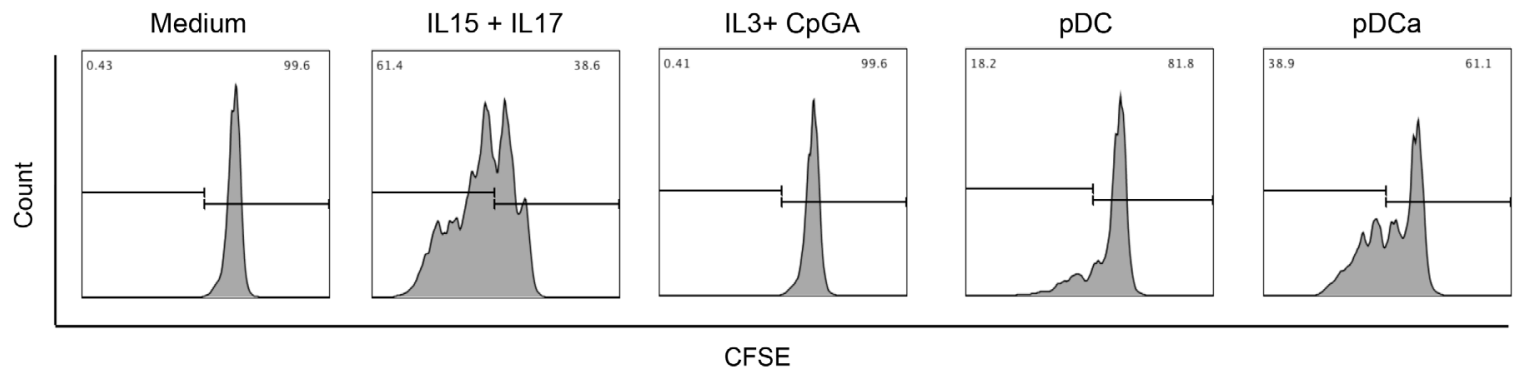

Figure 1: Human activated pDCs induce $\mathrm{V} \gamma 9 \mathrm{~V} \delta 2 \mathrm{~T}$ cells proliferation. Immature or activated pDCs were co-cultured with purified, CFSE-labeled $\mathrm{V} \gamma 9 \mathrm{~V} \delta 2 \mathrm{~T}$ cells for 6 days. a. shows cumulative data of $\mathrm{V} \gamma 9 \mathrm{~V} \delta 2 \mathrm{~T}$ cells division, as assessed by CSFE. Error bars indicate the mean with $\mathrm{SD}\left({ }^{*} p<0.05\right)$ from 12 individual experiments, each carried out in triplicate. b. shows flow cytometry histogram of a representative experiment. Viable lymphocytes were gated by forward and side scatter, and analysis was performed on 100,000 acquired events for each sample by using FlowJo and the following gating strategy to detect lymphocytes: FSC/SSC, live cells, single cells, double positive CD3 and $\mathrm{V} \gamma 9 \mathrm{~V} \delta 2 \mathrm{~T}$ cells. 
pDCs induced substantial proliferation $(48.3 \% \pm 12.5)$ which was comparable to that achieved by $\mathrm{V} \gamma 9 \mathrm{~V} \delta 2$ upon stimulation with the homeostatic cytokines IL-7 and IL-15 $(60.3 \% \pm 17)$ used as positive controls. Culture with IL-3 and $\mathrm{CpG}-\mathrm{A}$ alone failed to induce detectable proliferation of $\mathrm{V} \gamma 9 \mathrm{~V} \delta 2 \mathrm{~T}$ cells $(1.8 \% \pm 1.1)$, thus excluding any direct effect of these two stimuli on $\mathrm{V} \gamma 9 \mathrm{~V} \delta 2 \mathrm{~T}$ cells.

Proliferation of $\mathrm{V} \gamma 9 \mathrm{~V} \delta 2 \mathrm{~T}$ cells was strictly dependent on the number of activated $\mathrm{pDCs}$, with significant proliferation achieved at $\mathrm{pDCs} / \mathrm{V} \gamma 9 \mathrm{~V} \delta 2 \mathrm{~T}$ cell ratio of $1: 1$ and 5:1, while no proliferation of $\mathrm{V} \gamma 9 \mathrm{~V} \delta 2 \mathrm{~T}$ cells was detected when the number of activated pDCs was lower than that of $\mathrm{V} \gamma 9 \mathrm{~V} \delta 2 \mathrm{~T}$ cells $(0.1: 1$ and $0.01: 1$ ratios).

Figure 2a shows cumulative data from 5 individual experiments and Figure $2 \mathrm{~b}$ shows representative data.

\section{pDCs-induced $\mathrm{V} \gamma 9 \mathrm{~V} \delta 2 \mathrm{~T}$ cell proliferation requires cell to cell contact}

$\mathrm{V} \gamma 9 \mathrm{~V} \delta 2 \mathrm{~T}$ cells required contact with activated pDCs to proliferate, because when the cells were co- cultured separated by a transwell membrane to allow free exchange of soluble factors between upper and lower chambers in the absence of contact, $\mathrm{V} \gamma 9 \mathrm{~V} \delta 2 \mathrm{~T}$ cells consistently failed to proliferate (Figure $3 \mathrm{a}$ ). To further exclude the possibility that pDCs-induced $\mathrm{V} \gamma 9 \mathrm{~V} \delta 2 \mathrm{~T}$ cell proliferation was due to soluble factors produced upon contact between these two populations, activated pDCs and $\mathrm{V} \gamma 9 \mathrm{~V} \delta 2 \mathrm{~T}$ cells were put together in the upper chamber and CFSE-labelled V $\gamma 9 \mathrm{~V} \delta 2 \mathrm{~T}$ cells were cultured in the lower chamber. As shown in Figure $3 \mathrm{a}, \mathrm{V} \gamma 9 \mathrm{~V} \delta 2$ $\mathrm{T}$ cells failed to proliferate even under this experimental condition, clearly indicating that pDCs-induced proliferation of $\mathrm{V} \gamma 9 \mathrm{~V} \delta 2 \mathrm{~T}$ cells requires cell to cell contact and no soluble factor is involved in this interaction.

In previously published papers, different membrane molecules have been implicated in $\mathrm{V} \gamma 9 \mathrm{~V} \delta 2 \mathrm{~T}$ cell activation induced by several cell types including myeloid DCs, monocytes and NK cells [8]. Hence, a large panel of molecules potentially expressed by pDCs or $\mathrm{V} \gamma 9 \mathrm{~V} \delta 2$ $\mathrm{T}$ cells, including the $\gamma \delta \mathrm{TCR}, \mathrm{CD} 3, \mathrm{NKG} 2 \mathrm{D}, \mathrm{CD} 80$, CD86, CD40L, ICOS-L, OX40, and CD11, was screened using specific mAbs. However in our experimental model,

a

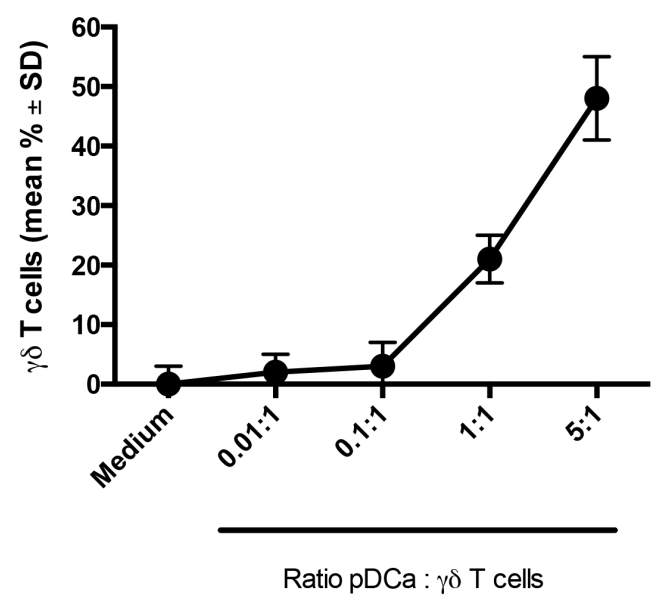

Ratio pDCa : $\gamma \delta$ T cells

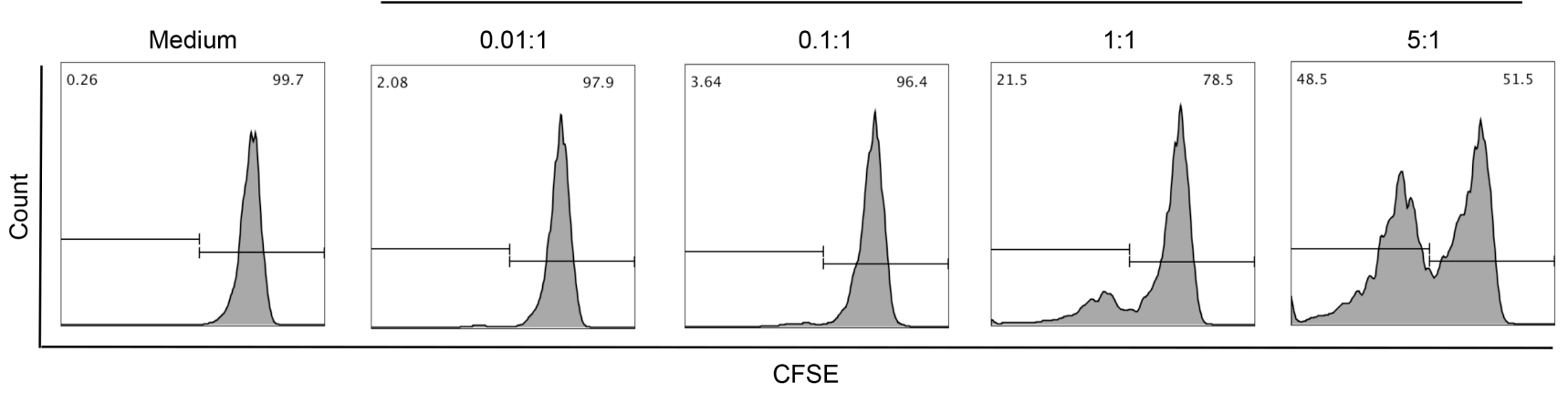

Figure 2: Enhanced proliferation of $\mathrm{V} \gamma \mathbf{9 V \delta 2} \mathrm{T}$ cells with higher $\mathrm{pDC} / \mathrm{V} \mathbf{9 V} \boldsymbol{\delta} 2 \mathrm{~T}$ cells ratio. a. Percentage of proliferating $\mathrm{V} \gamma 9 \mathrm{~V} \delta 2 \mathrm{~T}$ cells at different $\mathrm{pDC}: \mathrm{V} \gamma 9 \mathrm{~V} \delta 2 \mathrm{~T}$ cells ratio are shown. b. Flow cytometry panels (histogram plots)of a representative experiment are shown. The gating strategy is the same as described in the legend to Figure 1. 
blocking of any individual costimulatory molecule did not affect proliferation of $\mathrm{V} \gamma 9 \mathrm{~V} \delta 2 \mathrm{~T}$ cells (data not shown). mAbs to ICOS-L and CD40L caused an approximately $30 \%$ inhibition of pDCa-induced $\mathrm{V} \gamma 9 \mathrm{~V} \delta 2 \mathrm{~T}$ cell proliferation (Figures $3 \mathrm{~b}$ and $3 \mathrm{c}$ ), but inhibition did not attain statistical significance and did not increase upon addition of the two mAbs together (data not shown). Altogether, these results indicate that $\mathrm{V} \gamma 9 \mathrm{~V} \delta 2 \mathrm{~T}$ cell proliferation by pDCs does not require any of the tested membrane-bound costimulatory molecules. Thus, although interaction between cell surface molecules and counter ligands is involved, the nature of these molecules remains unclear at the moment.

\section{pDC-expanded $\mathrm{V} \gamma 9 \mathrm{~V} \delta 2 \mathrm{~T}$ cells show central memory phenotype}

In order to assess the differentiation pattern of $\mathrm{pDC}$ expanded $\mathrm{V} \gamma 9 \mathrm{~V} \delta 2 \mathrm{~T}$ cells, staining for CD45RA and $\mathrm{CD} 27$ was performed on $\mathrm{V} \gamma 9 \mathrm{~V} \delta 2 \mathrm{~T}$ cells after 6 days of co-culture with activated pDCs (Figures 4a and 4b) [9]. As expected, the majority of $\mathrm{V} \gamma 9 \mathrm{~V} \delta 2 \mathrm{~T}$ cells purified from buffy-coats had a $\mathrm{T}_{\mathrm{CM}}$ phenotype $(60 \% \pm 5)$, but also consisted of cells with a $\mathrm{T}_{\mathrm{EM}}$ phenotype $(24.8 \% \pm 5)$ and few cells with $\mathrm{T}_{\text {naìve }}(14 \% \pm 4)$ and $\mathrm{T}_{\mathrm{EMRA}}(0.7 \% \pm 1)$ phenotypes.

After culture with activated pDCs, the majority of cells retained $\mathrm{T}_{\mathrm{CM}}(50 \% \pm 7)$ and $\mathrm{T}_{\mathrm{EM}}(35 \% \pm 7)$ phenotypes, while the percentage of naive cells decreased (from 14\% \pm 4 to $10 \% \pm 2$ ).

PAg (BrHPP)-activated V $\gamma 9 \mathrm{~V} \delta 2 \mathrm{~T}$ cells showed a predominance of $\mathrm{T}_{\mathrm{EM}}(54 \% \pm 3)$ and $\mathrm{T}_{\mathrm{CM}}(42 \% \pm 9)$ phenotype, while $\mathrm{V} \gamma 9 \mathrm{~V} \delta 2 \mathrm{~T}$ cells that had been stimulated with BrHPP and activated pDC showed a similar phenotype distribution to those cultured with pDCs alone. These results indicate that activated pDCs trigger $\mathrm{V} \gamma 9 \mathrm{~V} \delta 2$ $\mathrm{T}$ cell division with maintenance of a $\mathrm{T}_{\mathrm{CM}}$ phenotype, but are poorly capable to promote long-term ex vivo differentiation of activated $\mathrm{V} \gamma 9 \mathrm{~V} \delta 2 \mathrm{~T}$ cells into effector memory cells. a

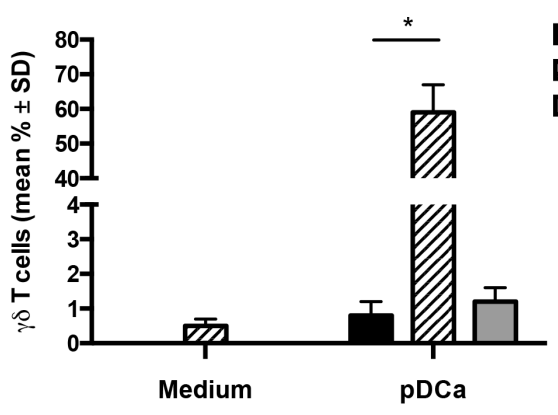

b

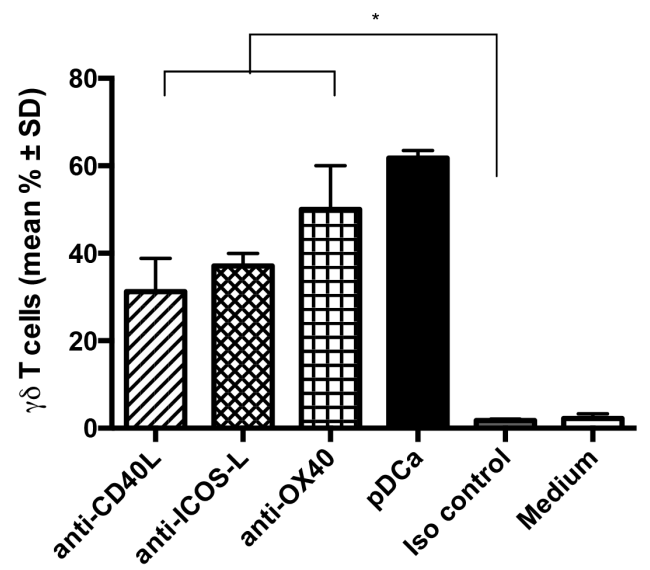

C

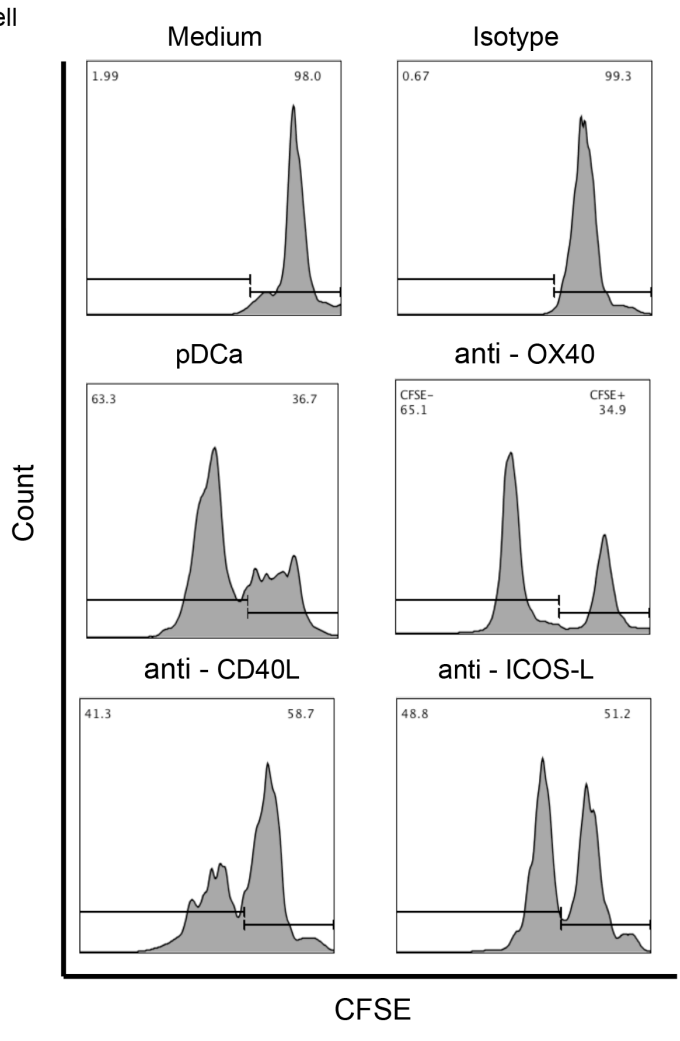

Figure 3: pDCs-induced $\mathrm{V} \gamma \mathbf{9} \mathbf{V} \delta 2 \mathrm{~T}$ cells proliferation requires cell to cell contact. a. Frequency of proliferating $\mathrm{V} \gamma 9 \mathrm{~V} \delta 2 \mathrm{~T}$ cells when put in cell to cell contact, or in transwell experiment with or without contact $\left({ }^{*} p<0.01\right)$. b. V $\gamma 9 \mathrm{~V} \delta 2 \mathrm{~T}$ cell proliferation by pDCs in the presence of mAbs to CD40L, ICOS-L and OX40. Isotype-matched mAbs and medium alone were used as controls. Error bars indicate the mean $\pm \mathrm{SD}(* p<0.01)$. c. Flow cytometry panels of a representative experiment demonstrate the percentage of proliferating V $\gamma 9 \mathrm{~V} 82 \mathrm{~T}$ cells in presence of CD40L, ICOS-L and OX40 blocking mAbs, using the gating strategy described in the legend to Figure 1. 


\section{Activated pDCs selectively induce IL-17 production by $\mathrm{V} \gamma 9 \mathrm{~V} \delta 2 \mathrm{~T}$ cells}

We next analysed if activated pDCs could induce cytokine production by $\mathrm{V} \gamma 9 \mathrm{~V} \delta 2 \mathrm{~T}$ cells. Responses were compared to those promoted by the $\mathrm{V} \gamma 9 \mathrm{~V} \delta 2 \mathrm{~T}$ cell-specific PAg BrHPP, which is well known to trigger a range of type-1 cytokines production (IFN- $\gamma$ and TNF- $\alpha$ ) by $\mathrm{V} \gamma 9 \mathrm{~V} \delta 2 \mathrm{~T}$ cell lines. Intracellular FACS analysis (Figures $5 \mathrm{a}$ and $5 \mathrm{~b}$ ) showed that activated pDCs induced very poor, if any, IFN- $\gamma$ production by $\mathrm{V} \gamma 9 \mathrm{~V} \delta 2 \mathrm{~T}$ cells, as compared to stimulation by Ionomycin and PMA used as a positive control $(4.43 \% \pm 0.23$ versus $40 \% \pm 2)$. BrHPP activated $\mathrm{V} \gamma 9 \mathrm{~V} \delta 2 \mathrm{~T}$ cells also produced significant IFN- $\gamma(11.8 \%$ \pm 3 ). Surprisingly, we found that $\mathrm{V} \gamma 9 \mathrm{~V} \delta 2 \mathrm{~T}$ cells were allowed to produce significant amounts of IL-17 upon coculture with activated $\mathrm{pDCs}$, while none of the other tested stimuli was capable to induce IL-17 production. Similar results were obtained by the measurement of IL-17 and IFN- $\gamma$ concentrations in culture supernatants by ELISA (Figure 5c).

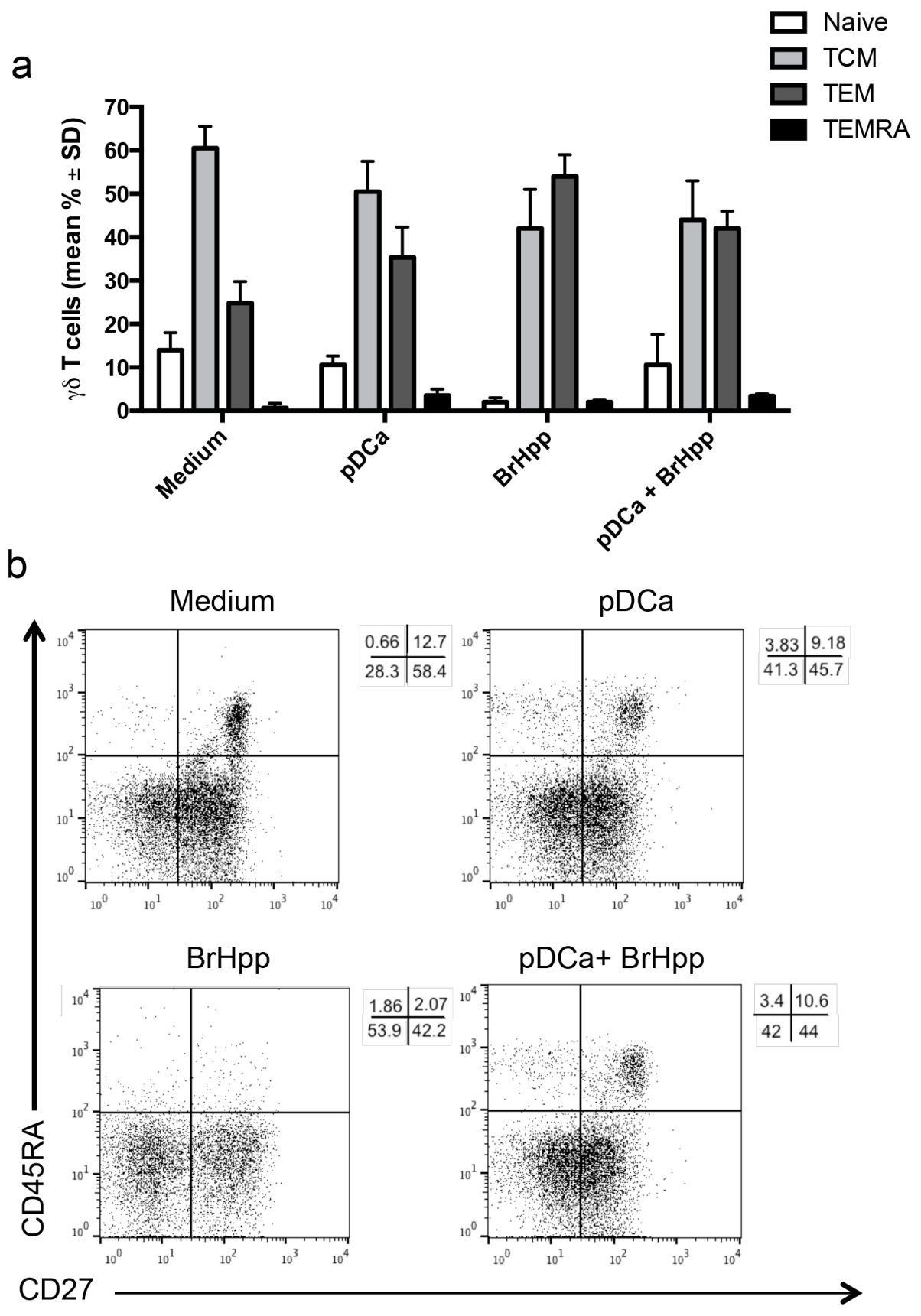

Figure 4: pDCs-expanded $V \gamma \mathbf{9 V} \delta 2$ T cells have memory phenotype. V $\gamma 9 \mathrm{~V} \delta 2 \mathrm{~T}$ cells were cultured with pDCs or other stimuli as described in Materials and Methods. At the end of the culture period, cells were stained with mAbs to CD45RA and CD27 after gating on the $\mathrm{V} \gamma 9 \mathrm{~V} \delta 2^{+} \mathrm{T}$ cells population. a. Bar graphs (mean $\pm \mathrm{SD}$ ) and $\mathbf{b}$. flow cytometry analysis of one representative experiment. 


\section{DISCUSSION}

It is generally accepted that $\mathrm{T}$ cell differentiation, expansion and survival are enforced in response to cues delivered by DCs. In humans, DCs are divided into two classes: myeloid and plasmacytoid DCs $[10,11]$. These latter are a unique population of bone-marrow-derived immune cells that reside primarily in lymphoid organs in the steady state, entering the lymph nodes from the blood $[12,13]$. pDCs express endosomal nucleic acidsensing TLR7 and TLR9 and respond to the respective ligands. The most distinct pDC response to these stimuli is rapid and abundant type-I IFN secretion [14]. Other consequences of TLR-induced pDC activation include the secretion of cytokines such as TNF- $\alpha$ and (in the mouse) IL-12 and the acquisition of antigen presentation ability. In addition to cytokine secretion, activated pDCs undergo a characteristic DC maturation program involving upregulation of co-stimulatory molecules and acquisition of $\mathrm{T}$ cell stimulation capacity. Altogether, these powerful immunostimulatory functions of $\mathrm{pDCs}$ contribute to the

a

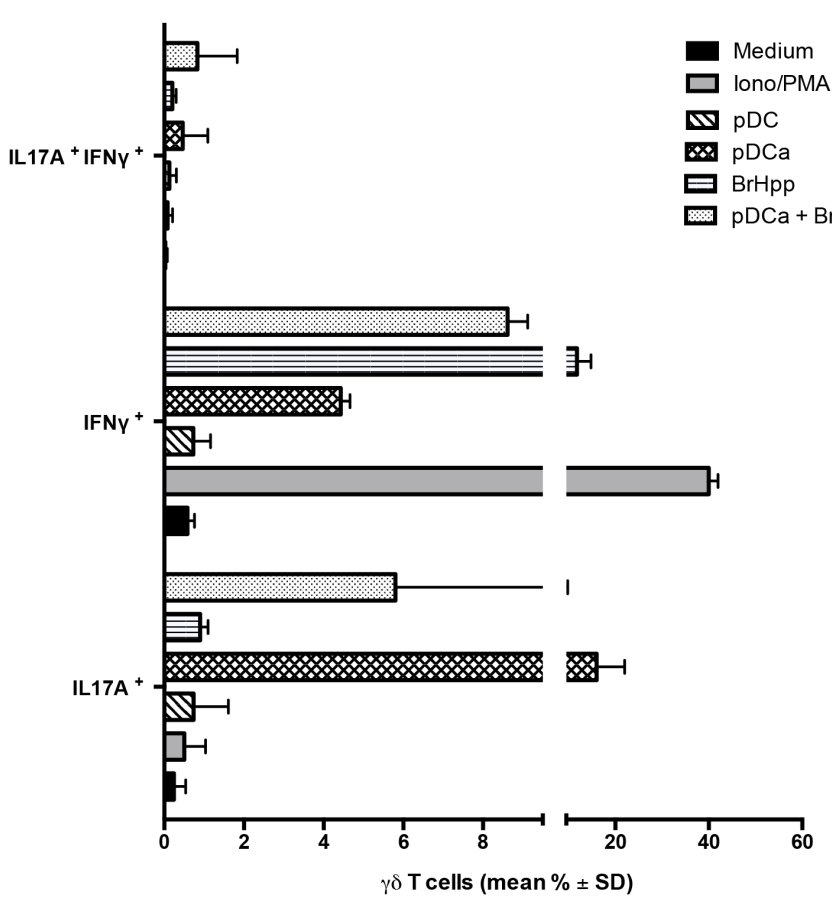

recruitment and/or activation of nearly all immune cell types $[15,16]$, establishing pDCs as a key link between innate and adaptive immunity.

A previously published study has shown that $\mathrm{V} \gamma 9 \mathrm{~V} \delta 2 \mathrm{~T}$ cell clones secrete IFN- $\gamma$ upon 24-hrs in vitro stimulation by TLR8/9-activated pDCs [7], but it is still unclear whether pDCs cells can induce full activation of resting $\mathrm{V} \gamma 9 \mathrm{~V} \delta 2 \mathrm{~T}$ cells upon TLR ligand stimulation.

In this study we show that pDCs activated by TLR stimuli and IL-3 are fully capable to induce proliferation of $\mathrm{V} \gamma 9 \mathrm{~V} \delta 2 \mathrm{~T}$ cells at a $1: 1$ or $5: 1 \mathrm{pDC} / \mathrm{V} \gamma 9 \mathrm{~V} \delta 2 \mathrm{~T}$ cell ratio.

Previous reports have demonstrated efficient in vitro $\mathrm{DC}$ maturation mediated by $\mathrm{PAg}-$ or aminobisphosphonate-stimulated $\mathrm{V} \gamma 9 \mathrm{~V} \delta 2 \mathrm{~T}$ cells [17], which involved both membrane-bound (i.e. CD40L) and soluble (i.e. TNF- $\alpha$ and IFN- $\gamma$ ) T cell-derived signals [18]. In our experimental model, transwell experiments clearly demonstrated that $\mathrm{pDCs}$-induced proliferation of $\mathrm{V} \gamma 9 \mathrm{~V} \delta 2$ $\mathrm{T}$ cells primarily involves cell to cell contact and does not require soluble factors. The possible implication of several candidate costimulatory molecules differentially expressed

$$
\text { b }
$$
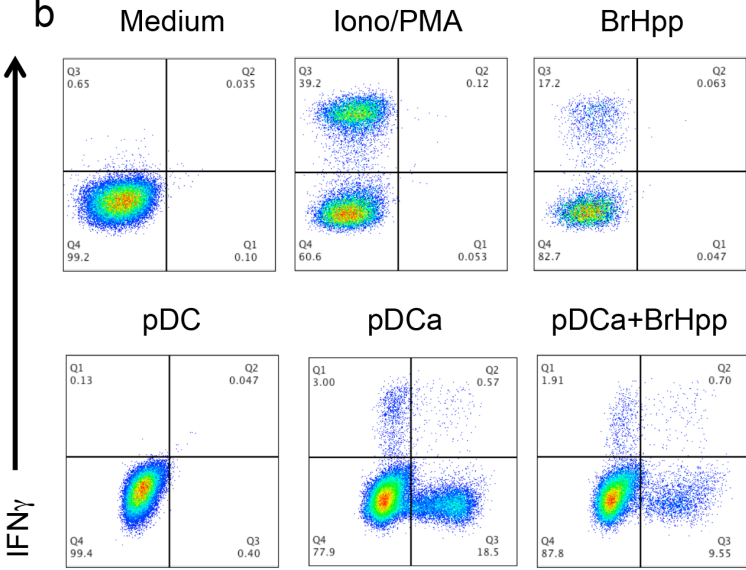

$\mathrm{pDCa}$

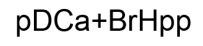

IL17
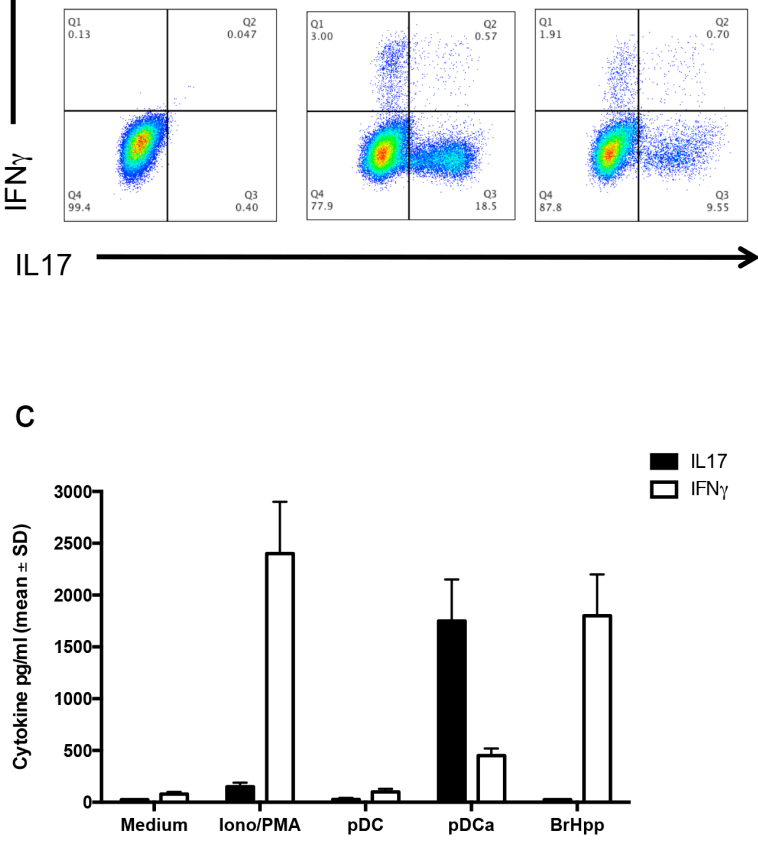

Figure 5: pDCs-expanded Vy9V82 T cells preferentially produce IL-17. a. Cumulative data of IFN- $\gamma$ and IL-17 producing $\mathrm{V} \gamma 9 \mathrm{~V} \delta 2 \mathrm{~T}$ cells in the presence or absence of activated pDCs or other stimuli. Data shown are mean $\pm \mathrm{SD}$. b. shows flow cytometry panels of a representative experiment. c. ELISA of IL-17 and IFN- $\gamma$ in supernatants of $\mathrm{V} \gamma 9 \mathrm{~V} \delta 2 \mathrm{~T}$ cells cultured for 6 days with pDCs or other stimuli. Data are shown as mean $\pm \mathrm{SD}$ and are representative of three separate experiments, each carried out in triplicate. 
by pDCs was studied by means of blocking reagents, but did not led to any conclusive results to date. Analysis of the effect of inhibitors of various signalling cascades as well as transcriptome analysis of maturing pDCs at various time points should certainly help to identify the mechanisms underlying such a potentiation effect. In addition, given that ICOS and OX40 are involved in the tolerogenic properties of pDCs [19, 20], we performed blocking studies using anti-OX40, anti-CD40L and antiICOSL, all of which failed to inhibit pDCs-induced $\mathrm{V} \gamma 9 \mathrm{~V} \delta 2 \mathrm{~T}$ cells proliferation.

Surprisingly, and in contrast with previously published findings, activated pDCs selectively induced IL17 responses of $\mathrm{V} \gamma 9 \mathrm{~V} \delta 2 \mathrm{~T}$ cells, and this was associated to the expansion of memory (both central and effector memory) subsets of $\mathrm{V} \gamma 9 \mathrm{~V} \delta 2 \mathrm{~T}$ cells. In fact, a previous study showed that pDCs stimulated by CpG ODN2216 induced exclusive IFN- $\gamma$ production by $\mathrm{V} \gamma 9 \mathrm{~V} \delta 2 \mathrm{~T}$ cell clones in a $24 \mathrm{hrs}$ co-culture. This was attributed exclusively to type-I IFN produced by TLR-stimulated pDCs. In agreement with data here reported, in rats and mice mature pDCs, but not myeloid DCs, support Th17 differentiation from naive $\mathrm{T}$ cells through secretion of high amounts of IL-6 [21].Similarly, human peripheral bloodderived pDCs activated with IL-3 and CpG secrete high amounts of IL-6 and TNF- $\alpha$, in addition to type-I IFN, but fail to promote IFN- $\gamma$ production upon co-culture with naive CD4 $\mathrm{T}$ cells [22]. Moreover, human and mouse pDCs promote differentiation of Th17 responses upon TLR-mediated activation [23, 24]. Finally, pDCs efficiently induced the differentiation of $\mathrm{T}$ cells producing only IL-22 (Th22) in naive T cells, in an IL-6- and TNF$\alpha$-dependent way [25]. Altogether, these results underline that $\mathrm{pDCs}$ have an intrinsic unique capacity to induce IL-17 and or IL-22, but not IFN- $\gamma$ secretion from T cells, including $\mathrm{V} \gamma 9 \mathrm{~V} \delta 2 \mathrm{~T}$ cells.

Typically, human $\mathrm{V} \gamma 9 \mathrm{~V} \delta 2 \mathrm{~T}$ cells default toward type 1 cytokine production and predominantly produce IFN- $\gamma$ upon activation. However, under appropriate culture conditions, $\mathrm{V} \gamma 9 \mathrm{~V} \delta 2 \mathrm{~T}$ cells divert from this typical Th1-like phenotype and polarize to different cytokineproducing subsets. Thus, the addition of IL-1 $\beta$, IL-6, IL-23, and TGF- $\beta$ in combination with TCR triggering promotes expression of the transcription factor RORC and polarization to IL-17-producing $\mathrm{V} \gamma 9 \mathrm{~V} \delta 2 \mathrm{~T}$ cells, while stimulation by cytokines alone did not enhance IL-17 production. This finding is consistent with the idea that $\mathrm{V} \gamma 9 \mathrm{~V} \delta 2 \mathrm{~T}$ cells are polarized $\mathrm{T}$ cells and the cytokine milieu can further drive their differentiation. The commitment and plasticity of effector T cell subsets are probably regulated by the expression and balance of lineage-specifying transcription factors, antigenic stimulation, or cytokine microenvironment, suggesting that $\mathrm{V} \gamma 9 \mathrm{~V} \delta 2 \mathrm{~T}$ cells may differentiate into multifunctional cells able to trigger additional responses in the periphery
[27].

Previous studies have demonstrated that murine $\gamma \delta \mathrm{T}$ cells are an innate source of IL-17 without the need for TCR engagement by antigen [28-30].A striking consequence of these findings is that the role of the TCR in IL-17-producing $\gamma \delta$ T cells could be redundant, in line with their predetermined phenotype in the thymus without positive or negative selection. Accordingly, murine $\gamma \mathrm{T}$ cells acquire IL-17-producing potential in the neonatal thymus independently on encountering the specific antigen.

In contrast to mouse studies, TCR engagement is required for the differentiation of human IL-17-producing $\mathrm{V} \gamma 9 \mathrm{~V} \delta 2 \mathrm{~T}$ cells from naive precursors, which poses the question of how $\mathrm{V} \gamma 9 \mathrm{~V} \delta 2 \mathrm{~T}$ cells are stimulated to produce IL-17 by activated pDCs, apparently in the absence of TCR engagement.

In accordance with our results, Guery et al. [31] have demonstrated that Ag-presenting activated pDCs induce potent antigen-specific Th17 cells, suggesting that pDCs could be used not only as inflammatory cytokines producers but also as efficient APCs to improve tumor vaccine efficacy. Moreover, Takagi et al. [32] showed that in a murine model pDCs contribute to the generation of IL-17 producing $\gamma \delta$ T cells under TLR7-mediated inflammatory conditions, that play a crucial role in the initiation of psoriasiform plaque formation [33-34].

In conclusion, our results demonstrate for the first time that TLR-activated human pDCs stimulate proliferation and promote selective IL-17 responses of $\mathrm{V} \gamma 9 \mathrm{~V} \delta 2 \mathrm{~T}$ cells in an innate fashion, thus providing a mechanism through which these two populations of cells with innate immunity features may interact at sites of inflammation.

\section{MATERIALS AND METHODS}

\section{Human subjects}

Peripheral blood mononuclear cells (PBMC) were isolated from buffy-coats of healthy donors, obtained from the Blood Bank of the University Hospital "P. Giaccone", Palermo. All participants wrote informed consent.

\section{pDC and $\mathrm{V} \gamma 9 \mathrm{~V} \delta 2 \mathrm{~T}$ cells purification}

PBMCs were obtained by density gradient sedimentation using Ficoll/Hipaque (Pharmacia Biotech, Uppsala, Sweden). To isolate pDCs, PBMCs were preenriched using anti-BDCA-4 PE $\mathrm{mAb}$ and anti-PE microbeads (MACS; Miltenyi Biotec, Bergisch Gladbach, Germany), according to the manufacturer's instructions, and sorted by using a FACS Aria Cell Sorter (BD 
Biosciences, Mountain View, CA), which resulted in 99\% purity. The cells were then resuspended in RPMI 1640 (Euroclone, UK) supplemented with 10\% FCS (Hyclone, Invitrogen, Italy), L-glutamine ( $2 \mathrm{mM})$, Hepes buffer $(10 \mathrm{mM})$, and gentamycin $(10 \mu \mathrm{g} / \mathrm{ml})$ (Sigma-Aldrich, Germany). pDCs were activated following culture for 24 hrs in the presence of interleukin-3 (IL-3, R\&D System, $10 \mu \mathrm{g} / \mathrm{ml}$ ) and CpGA-ODN 2216 (TIB MolBiol, $3 \mu \mathrm{g} /$ $\mathrm{ml})$ in 96-well flat bottom plates (Costar). $\gamma \delta \mathrm{T}$ cells were separated from PBMC by positive selection using anti$\gamma \delta$-magnetic beads (Miltenyi Biotec) according to the manufacturer's instructions. Purified cell populations contained more than $98 \%$ of viable $\mathrm{V} \gamma 9 \mathrm{~V} \delta 2 \mathrm{~T}$ cells as assessed by flow cytometry.

\section{Co-colture of $\mathrm{V} \gamma 9 \mathrm{~V} \delta 2 \mathrm{~T}$ cells and pDC}

V $\gamma 9 \mathrm{~V} \delta 2 \mathrm{~T}$ cells were labelled with CFSE (Molecular Probes, Eugene, USA) and $2 \times 10^{5} \mathrm{~V} \gamma 9 \mathrm{~V} \delta 2 \mathrm{~T}$ cells were co-cultured with $2 \times 10^{5}$ activated pDC, in 96well round bottom plates (Costar, Cambridge, MA) for 6 days at $37^{\circ} \mathrm{C}, 5 \% \mathrm{CO}_{2}$. As a control CFSE-labelled $\mathrm{V} \gamma 9 \mathrm{~V} \delta 2 \mathrm{~T}$ cells were cultured with the PAg bromohydrin pyrophosphate (BrHPP, a generous gift of Dr. Jean Jacques Fourniè, 10nM final concentration) and IL-2 (20 $\mathrm{U} / \mathrm{ml}$ final concentration) as reported in Dieli et al [35]. IFN- $\gamma$ and IL-17 levels were measured in 6-day culture supernatants by ELISA according to the manufacturer's instructions (R\&D Systems). In some experiments, cocultures were carried out in the presence of blocking mAbs to CD40L, ICOS-L and OX40 or isotype-matched mAbs (all purchased from BD Bioscience, and used at $10 \mu \mathrm{g} / \mathrm{ml}$ final concentrations). To study the cell contact requirement, $\mathrm{V} \gamma 9 \mathrm{~V} \delta 2 \mathrm{~T}$ lymphocytes were physically separated from pDCs by a semipermeable membrane using transwell plates $(6.5-\mathrm{mm}$ diameter, $0.4-\mu \mathrm{m}$ pore size, Corning Glass Work, Corning, NY). V $\gamma 9 \mathrm{~V} \delta 2$ T cells on the lowest well were harvested after 6 days at $37^{\circ} \mathrm{C}$ by gentle pipetting in $\mathrm{PBS}$, washed, resuspended in medium and used for further analysis.

\section{Flow cytometry analysis}

The following antibodies were used: anti-IFN- $\gamma$, anti-IL17A, anti-CD3, anti-CD27, anti-CD45RA and isotype-matched control $\mathrm{mAbs}$, labelled with different fluorochromes, all purchased from BD Bioscience, and used according to the manufacturer's recommendations. $\mathrm{V} \gamma 9 \mathrm{~V} \delta 2 \mathrm{~T}$ cell proliferation was assessed after 6 days of co-culture according to loss of CFSE labelling in PI- cells. To study intracellular IFN- $\gamma$ and IL-17, V $\gamma 9 \mathrm{~V} \delta 2 \mathrm{~T}$ cells were co-cultured with activated pDCs, Ionomycin and PMA or with BrHPP in the presence of monensin for the last $5 \mathrm{hrs}$ at $37^{\circ} \mathrm{C}$ in $5 \% \mathrm{CO}_{2}$. The cells were harvested, washed twice in PBS with $1 \%$ FCS and fixed with PBS containing $4 \%$ paraformaldehyde overnight at $4{ }^{\circ} \mathrm{C}$. Fixation was followed by permeabilization with $\mathrm{PBS}$ containing $1 \% \mathrm{FCS}, 0.3 \%$ saponin, and $0.1 \% \mathrm{Na}$ azide for $15 \mathrm{~min}$ at $4^{\circ} \mathrm{C}$. Staining of intracellular cytokines were performed by incubation of fixed permeabilized cells with FITC-labelled anti-IFN- $\gamma$ and APC-labelled antiIL17A mAbs. After two more washes in PBS containing $1 \%$ FCS, the cells were analyzed by FACS CANTO II flow cytometer (BD Bioscience). Viable lymphocytes were gated by forward and side scatter, and analysis was performed on 100,000 acquired events for each sample by using FlowJo and the following gating strategy to detect lymphocytes from FSC/SSC, live cells, single cells, double positive CD3, and TCR V $\gamma 9 \mathrm{~V} \delta 2$ cells.

\section{Statistical analysis}

Data were analyzed with Mann-Whitney test, and two-tailed Student's t test was used to compare significance of differences between groups. Data from different experiments were compared using one-way ANOVA Kruskal-Wallis multiple comparison test with Bonferroni correction, by usingGraphPad. Values of $p<$ 0.05 were considered statistically significant.

\section{ACKNOWLEDGMENTS}

We would like to thank Jean Jacques Fourniè (CRCT, UMR1037, Inserm-Univ. Toulouse III Paul SabatierERL5294 CNRS, Toulouse, France) for the generous gift of BrHPP, Chiara Romagnani, Andreas Thiel and Andreas Radbruch (DeutschesRheuma Forschungszentrum (DRFZ) Berlin, Leibniz-Gemeinschaft, Berlin, Germany) for help and advice. We also thank the Blood Bank staff of the University Hospital "P. Giaccone", Palermo for the buffycoats of healthy donors.

\section{CONFLICTS OF INTEREST}

The authors declare no financial or commercial conflict of interest.

\section{Editorial note}

This paper has been accepted based in part on peerreview conducted by another journal and the authors' response and revisions as well as expedited peer-review in Oncotarget.

\section{REFERENCES}

1. Swiecki M, Colonna M. The multifaceted biology of 
plasmacytoid dendritic cells. Nat Rev Immunol. 2015; 15:471-485.

2. Shirota H, Tross D, Klinman DM. CpG Oligonucleotides as Cancer Vaccine Adjuvants. Vaccines (Basel). 2015; 3:390407.

3. Proietto AI, O'Keeffe M, Gartlan K, Wright MD, Shortman K, Wu L, Lahoud MH. Differential production of inflammatory chemokines by murine dendritic cell subsets. Immunobiology. 2004; 209:163-172.

4. Villadangos JA, Young L. Antigen-presentation properties of plasmacytoid dendritic cells. Immunity. 2008; 29:352361.

5. Lo Presti E, Dieli F, Meraviglia S. Tumor-infiltrating $\gamma \delta$ $\mathrm{T}$ lymphocytes: pathogenic role, clinical significance and differential programming in the tumor microenvironment. Front Immunol. 2014; 5; 607.

6. Dieli F, Poccia F, Lipp M, Sireci G, Caccamo N, Di Sano C, Salerno A. Differentiation of effector/memory V $\delta 2$ T cells and migratory routes in lymph nodes or inflammatory sites. J Exp Med. 2003; 198: 391-397.

7. Devilder MC, Allain S, Dousset C, Bonneville M, Scotet E. Early triggering of exclusive IFN- responses of human $\mathrm{V} \gamma 9 \mathrm{~V} \delta 2 \mathrm{~T}$ cells by TLR-activated myeloid and plasmacytoid dendritic cells. J Immunol. 2009; 183: 36253633.

8. Conti L, Casetti R, Cardone M, Varano B, Martino A, Belardelli F, Poccia F, Gessani S. Reciprocal activating interaction between dendritic cells and pamidronatestimulated $\gamma \delta \mathrm{T}$ cells: role of CD86 and inflammatory cytokines. J Immunol. 2005; 174: 252-260.

9. Caccamo N, Meraviglia S, Ferlazzo V, Angelini D, Borsellino G, Poccia F, Battistini L, Dieli F, Salerno A. Differential requirements for antigen or homeostatic cytokines for proliferation and differentiation of human V $\gamma 9 \mathrm{~V} \delta 2$ naive, memory and effector T cell subsets. Eur J Immunol. 2005; 35: 1764-1772.

10. Shortman K, Naik SH. Steady-state and inflammatory dendritic-cell development. Nat Rev. Immunol. 2007; 7:1930 .

11. Villadangos JA, Schnorrer P. Intrinsic and cooperative antigen-presenting functions of dendritic-cell subsets in vivo.Nat Rev. Immunol. 2007; 7: 543-555.

12. Sozzani S, Vermi W, Del Prete A, Facchetti F. Trafficking properties of plasmacytoid dendritic cells in health and disease. Trends Immunol. 2010; 31: 270-277.

13. Randolph GJ, Ochando J, Partida-Sanchez S. Migration of dendritic cell subsets and their precursors. Annu Rev Immunol. 2008; 26: 293-316.

14. Sandberg K, Eloranta ML, Johannisson A, Alm GV. Flow cytometric analysis of natural interferon- $\alpha$ producing cells. Scand. J Immunol. 1991; 34: 565-576.

15. Krug A, French AR, Barchet W, Fischer JA, Dzionek A, Pingel JT, Orihuela MM, Akira S, Yokoyama WM,
Colonna M. TLR9-dependent recognition of MCMV by IPC and DC generates coordinated cytokine responses that activate antiviral NK cell function. Immunity. 2004; 21:107-119.

16. Jego G, Palucka AK, Blanck JP, Chalouni C, Pascual V, Banchereau J. Plasmacytoid dendritic cells induce plasma cell differentiation through type I interferon and interleukin 6. Immunity. 2003; 19: 225-234.

17. Ismaili, J, Olislagers, V, Poupot, R, Fournie, JJ, Goldman, M. Human $\gamma \delta$ T cells induce dendritic cell maturation. Clin Immunol. 2002; 103: 296-302.

18. Leslie DS, Vincent MS, Spada FM, Das H, Sugita M, Morita CT, Brenner MB. CD1-mediated $\gamma \delta \mathrm{T}$ cell maturation of dendritic cells. J Exp Med. 2002; 196:15751584.

19. Ito T, Yang M, Wang YH, Lande R, Gregorio J, Perng OA, Qin XF, Liu YJ, Gilliet M. Plasmacytoid dendritic cells prime IL-10-producing $\mathrm{T}$ regulatory cells by inducible costimulator ligand. J Exp Med. 2007; 204:105-115.

20. Ito T, Amakawa R, Inaba M, Hori T, Ota M, Nakamura K, Takebayashi M, Miyaji M, Yoshimura T, Inaba K, Fukuhara S. Plasmacytoid dendritic cells regulate Th cell responses through OX40 ligand and type I IFNs. J Immunol. 2004; 72: 4253-4259.

21. Gautreau L, Chabannes D, Heslan M, Josien R. Modulation of regulatory T cell-Th17 balance by plasmacytoid dendritic cells. J Leukoc Biol. 2011; 90: 521-527.

22. Hostmann A, Kapp K, Beutner M, Ritz JP, Loddenkemper C, Ignatius R, Duchmann R, Daum S, Gröne J, Hotz H, Buhr HJ, Zeitz M, Ullrich R. Dendritic cells from human mesenteric lymph nodes in inflammatory and noninflammatory bowel diseases: subsets and function of plasmacytoid dendriticcells. Immunology. 2013; 139: 100108.

23. Isaksson M, Ardesjö B, Rönnblom L, Kämpe O, Lassmann H, Eloranta ML, Lobell A. Plasmacytoid DC promote priming of autoimmune Th17 cells and EAE. Eur J Immunol. 2009; 39: 2925-2935.

24. Yu CF, Peng WM, Oldenburg J, Hoch J, Bieber T, Limmer A, Hartmann G, Barchet W, Eis-Hübinger AM, Novak N. Human plasmacytoid dendritic cells support Th17 cell effector function inresponse to TLR7 ligation. J Immunol. 2010; 184: 1159-1167.

25. Bonnefoy F, Perruche S, Couturier M, Sedrati A, Sun Y, Tiberghien P, Gaugler B, Saas P. Plasmacytoid dendritic cells play a major role in apoptotic leukocyte-induced immune modulation. J Immunol. 2011; 186: 5696-5705.

26. Duhen T, Geiger R, Jarrossay D, Lanzavecchia A, Sallusto F. Production of interleukin 22 but not interleukin 17 by a subset of human skin-homing memory Tcells. Nat. Immunol. 2009; 10: 857-863.

27. Zhou L, Lopes JE, Chong MM, Ivanov II, Min R, Victora GD, Shen Y, Du J, Rubtsov YP, Rudensky AY, Ziegler SF, 
Littman DR. TGF- $\beta$-induced Foxp3 inhibits T(H)17 cell differentiation by antagonizing ROR $\gamma$ t function. Nature. 2008; 453: 236-240.

28. Serre K, Silva-Santos B. Molecular mechanisms of differentiation of murine pro-Inflammatory $\gamma \delta \mathrm{T}$ Cell Subsets. Front Immunol. 2013; 5:431.

29. SchmolkaN, Wencker M, Hayday AC, Silva-Santos B. Epigenetic and transcriptional regulation of $\gamma \delta \mathrm{T}$ cell differentiation: Programming cells for responses in time and space. Semin Immunol. 2015; 27:19-25.

30. Schmolka N, Wencker M, Hayday AC, Silva-Santos B. Epigenetic and transcriptional signatures of stable versus plastic differentiation of proinflammatory $\gamma \delta$ T cell subsets. Nat Immunol. 2015; 14:1093-1100.

31. Guéry L, Dubrot J, Lippens C, Brighouse D, Malinge P, Irla M, Pot C, Reith W, Waldburger JM, Hugues S. Agpresenting CpG-Activated pDCs prime Th17 cells that induce tumor regression. Cancer Research. 2014; 74: 64306440 .
32. Takagi H, Arimura K, Uto T, Fukaya T, Nakamura T, Choijookhuu N, Hishikawa Y, Sato K. Plasmacyotid dendritic cells orchestrate TLR7-mediated innate and adaptive immunity for the initiation of autoimmune inflammation. Scientific Reports. 2015; 6: 1-16.

33. Cai Y, Shen X, Ding C, Qi C, Li K, Li X, Jala VR, Zhang HG, Wang T, Zheng J, Yan J. Pivotal role of dermal IL-17 producing $\gamma \delta \mathrm{T}$ cells in skin inflammation. Immunity. 2011; 35:596-610.

34. Pantelyushin S1, Haak S, Ingold B, Kulig P, Heppner FL, Navarini AA, Becher B. Roryt+ innate lymphocytes and $\gamma \delta \mathrm{T}$ cells initiate psoriasiform plaque formation in mice. $\mathrm{J}$ Clin Invest. 2012; 122:2252-2256.

35. Sireci G, Espinosa E, Di Sano C, Dieli F, Fournié JJ, Salerno A. Differential activation of human gammadelta cells by nonpeptide phosphoantigens. Eur J Immunol. 2001; 31:1628-1635. 